\title{
A NAGYVÁROSOK FELÉRTÉKELŐDÉSE A KÜLFÖLDI MÜKÖDÖTÖKE-BERUHÁZÁSOK TELEPHELYVÁLASZTÁSÁBAN
}

\author{
(Upgrade of big Cities in Choose of Foreign Active Capital \\ Investment's Domicile Business)
}

\section{KUKELY GYÖRGY}

Kulcsszavak:

külföldi müködötōke nagyváros budapesti metropolisz transznacionális vállalatok

A világon a fejlödés hajtóeröi a nagyvárosok. A nagyvárosok a külföldi müködötöke (KMT) beruházások fogadásában fontos, s egyre jelentỏsebb szerepet jâtszanak. Nemzetközi példák sora jelzi, hogy a külfoldi tôke telephelyválasztásában a nagyvárosokat, különös tekintettel a fövárosi ranggal is rendelkezôket preferálja. Magyarországon a budapesti metropolisz-térség kiemelkedõ szerepe másfél évtizede megkérdô. jelezhetetlen, s a KMT-befektetések új szakaszában a fỏvárosi agglomeráció súlya újra növekszik.

\section{A nagyvárosok növekvö szerepe a globális tőkemozgásokban}

Az elmúlt évtizedben a gazdaság globalizációjával az urbanizált régiók szerepe jelentősen felértékelődött: ma a nagyvárosok dominálják a posztindusztriális gazdaságot (Cséfalvay 1999; Erdösi 2003; Kratke 2006; Lengyel-Rechnitzer 2000).

A világgazdaság fó hajtóerejét a világvárosok, a globális városok jelentik (Sassen 1991). A nemzetközivé váló világban erősödik a városverseny, melyben a legjobb adottságokkal a nagyvárosok vesznek részt (Friedmann 1995). A városok sikerességében, versenyképességében központi szerepet játszik a nemzetközi gazdasági munkamegosztásba való bekapcsolódás mértéke. A nagyvárosok a modernizáció, a gazdasági-társadalmi fejlödés és a megújulás terei.

A posztindusztriális nagyvárosok fejlödése az információs gazdaságból és a tercierizálódásból táplálkozik. A nagyvárosokban koncentrálódnak a legfontosabb irányító és döntéshozó központok, a legfejlettebb üzleti szolgáltatások és a kutatófejlesztő bázisok. A nagyvárosok az innováció és a gazdaság húzóágazatainak helyei. Ezek ugyan mind hagyományosan városi jegyek, de ilyen mértékü koncentrációjuk új tendencia (Castells 1996). A nagyvárosi régiók a világgazdaság legversenyképesebb és legdinamikusabb terei: a globális tôkemozgások kitủntetett helyei. A nagyvárosok a térbeli koncentráció fơ előnyét jelentő szolgáltató és információs hálózatok csomópontjai (Enyedi 2001).

A globális gazdaság leginkább a nagyvárosi környezetben találja meg azokat az erőforrásokat és infrastruktúrát, mely a gazdaság szereplői, elsősorban a transznacionális vállalatok számára nemcsak fontos, hanem nélkưlözhetetlen tényezők. A metropoliszok nemcsak komplex gazdasági struktúrával rendelkeznek, hanem annak irányító 
funkcióit is magukhoz vonzzák. A nagyvárosi funkciók és intézmények, a pénzügyi és egyéb szolgáltatások, a szakképzett munkaerő, a felhalmozott tudás, a legmodernebb infrastruktúrák itt összpontosulnak. A nagyvárosok képezik az elsődleges fogyasztópiacot a globális gazdaság termékei számára.

A metropolizáció, a nagyvárosodás a gazdasági potenciál növekvő koncentrációjával jár, különösen az innovációvezérelt gazdaság kulcságazatai - a kutatásintenzív ipar és a tudásintenzív szolgáltatások - összpontosulása erősödik a nagyvárosi régiókban. A tudásintenzív tevékenységek területén meglévő gazdasági potenciál meghatározza, hogy egy nagyváros milyen feltételekkel tud bekapcsolódni a nemzetközi városversenybe, s mennyire bizonyul versenyképesnek az innovációvezérelt gazdaságban. Ezek révén lehetnek az európai nagyvárosi térségek az európai gazdaság motorjai és Európa világpiaci integrációjának fő csomópontjai.

A metropolizáció legfontosabb tényezői között Bourdeau-Lepage (2004) a fejlett üzleti szolgáltatások koncentrációját és a nagyvárosok globális hálózatába való integrálódását, a globális interakciókba és információáramlásba való bekapcsolódást sorolja fel. A nagyvárosok szerepét a globális hierarchiában jól jelzi a transznacionális vállalatok hálózatában elfoglalt szerepkör, különösen, ami a magas szintú szolgáltatások jelenlétét és koncentrációját jelenti.

A globalizációs folyamatok fó aktorai a transznacionális vállalatok, amelyek a termelés országhatárokon átnyúló megszervezésével behálózzák az egész világot (Erdösi 2003). A transznacionális vállalatok uralta globális gazdaságot a nagyvárosokból irányítják. Ezek a globális gazdasági hálózatok csomópontjai, ahol a gazdasági tevékenységek sürüsödnek (Krugman 2000), a döntések születnek - ezek a világgazdaság irányító helyei.

A globális városok ellenőrzik a világ erőforrásainak döntő hányadát. A globális városok közötti kapcsolatok alapján e nagyvárosok komplex térbeli hierarchiába rendeződnek, közöttük hálózat formálódik (Hall 1966, Friedmann 1995, Sassen 1991). A globalizáció fontos szerepet játszik az európai városrendszer fejlödésében. A világgazdaság új fejlődési szakaszában való aktív részvétel a világméretű gazdasági kapcsolatok intenzitásának növekedésével jár. Az európai városok közötti verseny egyre fokozódik.

A városversenyben az egyes városok pozíciója jelentős változáson megy keresztül, mely szoros összefüggésben van a gazdaság területi átrendeződésével is. A termelés globalizált, az irányítás világszinten szerveződik (Sykora 1996). A feldolgozóipar nagy része már nem a nagyvárosokban található, itt a vállalatok irányítóadminisztratív funkciói, s a tercier ágazatok válnak a húzóerővé. A transznacionális nagyvállalatok irányító és fejlesztö-központjai a legjelentösebb metropoliszokban koncentrálódnak. A rutinszerü, regionális, helyi piacokra épülő vállalatok inkább a nagyobb városok környékeire, vagy a kisebb városokba telepszenek (Sassen 2000). Ugyanakkor a tudásalapú termelötevékenységek továbbra is a nagyvárosokban maradnak, ill. ide összpontosulnak (IKT-szektor, gyógyszeripar, biotechnológia, médiaipar stb.). A high-tech ágazatok jellegzetesen a nagyvárosi centrumokban koncentrálódnak. Ugyancsak a nagyvárosi térségek gazdaságának fontos alkotói 
A nagyvárosok felértékelődése a külföldi müködőtőke-beruházások telephelyválasztásában. Tér és Társadalom 20. évf. 2006/4. 111-125. p.

TÉT XX. évf. 2006 - 4

Gyors ténykép

113

maradnak a hagyományos, technológiaközpontú termelő ágazatok (jármủgyártás, gépipar), elsősorban azok innovatív szegmensében. Az új gazdaság, a tudás alapú gazdaság fontos indikátora a magas szintủ innovációs kapacitás, a kutatás és fejlesztés jelentösége, valamint a felsőoktatás fejlettsége (Nagy 2006). A nagyvárosok versenyében számos város pozíciója javult (Barcelona, München, Bécs) (Keresztély-Jeney 2003), s hasonlóan felértékelődött a kelet-közép-európai régió nagyvárosainak is a helyzete.

\section{A kelet-közép-európai országok nagyvárosi térségeinek szerepe a külföldi múködötőke vonzásában}

Habár a nemzetállamok szerepe lecsökkent, de a fővárosok relatív jelentősége máig nagy. Kelet-Közép-Európában a fövárosok a nemzetközi gazdaság innovációs centrumai, s ök profitálnak elsősorban a nemzetközi pénzügyi tevékenységekböl (Lichtenberger 1994). A rendszerváltás utáni gazdasági átalakulás leginkább a nagyvárosoknak kedvezett, hiszen itt álltak rendelkezésre az átmenet legkedvezőbb feltételei: itt koncentrálódtak a gazdasági, politikai és igazgatási irányító funkciók, a képzett munkaerö aránya magasabb, $\mathrm{s}$ az infrastrukturális szint is fejlettebb volt. A rendszerváltás után a kelet-közép-európai országok nagyvárosai is bekapcsolódtak az európai városok versenyébe (Enyedi 1998). 1990 után ezekben az országokban, ill. fővárosaikban három folyamat zajlott egy időben: a politikai és gazdasági átmenet; a reintegráció a világgazdaságba, ill. az EU-csatlakozás; valamint a nagyvárosi térségek metropolizációs folyamata. Ennek legfontosabb szegmensét a fejlett üzleti szolgáltatások és az irányítási funkciók növekvő koncentrálódása jelenti.

Az európai integráció és a gazdasági globalizáció a városverseny intenzifikálódásához vezet. Kelet-Közép-Európában elsősorban a fövárosok tudtak bekapcsolódni a nemzetközi városversenybe. Ennek egyik oka, hogy Lengyelország kivételével a fövárosok a városrendszer egyetlen igazi nagyvárosai. 'Budapest, Prága és Varsó ma már nem elhanyagolható szereplök az európai nagyvárosok hálózatában sem, KeletKözép-Európában viszont stratégiai pozíciót töltenek be. A világvárosok rangsorában a kelet-közép-európai fövárosok ugyanazon a szinten helyezkednek el (Erdösi 2003), a nagyvárosok hierarchiájának harmadik szintjén (Friedmann 1995). Mindegyik kelet-közép-európai főváros kapuvárosi szereppel is bír egyrészt saját országa, másrészt a tőle keletre, délkeletre elhelyezkedö térségek felé.

A kelet-közép-európai országokban a rendszerváltás után felerösödött a területi differenciálódás, $\mathrm{s}$ elsösorban a fövárosok váltak a változás nyerteseivé. A fövárosok gazdasági fejlettsége és annak dinamikája minden országban jóval az országos átlag felett van, már annak kétszeresét is meghaladja. Ugyanakkor az 1990-es évekhez képest változás következett be: a fövárosi régiók szerepe továbbra is növekszik, de a fejlödés már sokkal dinamikusabb a föváros körüli agglomerációs gyürü terïletén. A nagyvárosok fejlődése egyre nagyobb térségre terjed ki, a kelet-középeurópai fỏvárosok metropolisszá válnak, a nagyváros és térsége között új munkamegosztás alakul ki. A GDP elöállításában a fövárosi régiók szerepe az 1990-es 
években minden kelet-közép-európai országban növekedett. Magyarországon a GDP egyharmada, Csehországban és Szlovákiában egynegyede, Lengyelországban egynyolcada koncentrálódik a fóvárosban (1. táblázat)

\begin{tabular}{lcc}
\multicolumn{3}{c}{$\begin{array}{c}\text { 1. TÁBLÁZAT } \\
\text { A fóvárosok aránya a GDP-böl (\%) } \\
\text { (Capital city's ratios of GDP \%) }\end{array}$} \\
\hline Budapest & 1995 & 2004 \\
Pozsony & 33,9 & 34,6 \\
Prága & 24,6 & $24,9^{*}$ \\
Varsó & 21,5 & 23,0 \\
\hline
\end{tabular}

Forrás: Eurostat, nemzeti statisztikai hivatalok *2003-as adat.

Kelet-Közép-Európában a KMT-állomány koncentrácioja növekszik, a külföldi beruházások legnagyobb része a fővárosi régiókba érkezett. A területi koncentráció alig változik, a fóvárosi agglomerációk dominanciája minden kis- és közepes nagyságú kelet-közép-európai országban stabilnak mondható, mindössze Budapest esetében beszélhetünk kisebb csökkenésről (2. táblázat).

\section{TÁBLÁZAT}

A müködőtőke-állomány koncentrációja a fövárosi régiókban Magyarországon, Szlovákiában és Csehországban ${ }^{2}$

(Concentration of Active Capital in Capital City Regions in Hungary, Slovakia and the Czech Republic)

\begin{tabular}{lcc}
\hline & 2000 & 2004 \\
\hline Közép-Magyarország & 67 & 64 \\
Pozsonyi régió & 55 & 68 \\
Prága & 47 & 47 \\
\hline
\end{tabular}

Forrás: KSH, Szlovák Nemzeti Bank, Cseh Nemzeti Bank.

A fejlett gazdaságokban a legdinamikusabban növekvő szektort, a legfontosabb húzóágazatot az üzleti szolgáltatások jelentik (Raffay 2005). A magas szintü üzleti szolgáltatások jelenléte a város sikertényezőinek fontos indikátora (Enyedi 1997). Az üzleti szolgáltatások szektorában foglalkoztatottak aránya ma Kelet-KözépEurópában, így Magyarországon is legfeljebb a fele a fejlett piacgazdaságokban jellemző értéknek (Bourdeau-Lepage 2004), Csehországban és Magyarországon is mindössze a foglalkoztatottak $8 \%$-a. Az üzleti szolgáltatások jellemzően a magasabb hierarchiaszinteken összpontosulnak, legdinamikusabb tevékenységei elsősorban a fơvárosban és a nagyvárosokban - koncentráltan - vannak jelen. A beruházások is ott koncentrálódnak, ahol tömegesen rendelkezésre állnak a megfelelő humán erőforrások azaz a nagyvárosokban. A fơvárosokban a munkaerỏ képzettsége magasabb szintü, 
A nagyvárosok felértékelödése a külföldi müködőtőke-beruházások telephelyválasztásában. Tér és Társadalom 20. évf. 2006/4. 111-125. p.

TÉT XX. évf. $2006 \mathbf{\square}$

Gyors ténykép

115

a nemzetkỏzi kapcsolatok eröteljesebbek. A fövárosok a gazdasági, a politikai és közigazgatási hatalom székhelyei. Mindezen tényezők a transznacionális vállalatok telephelyválasztásában egyaránt fontos szerepet játszanak.

$\mathrm{Az}$ üzleti szolgáltatások aránya a kelet-közép-európai nagyvárosokban jóval magasabb, mint az országos átlag. Az üzleti szolgáltatások által termelt hozzáadottérték nagy része, Magyarországon például több mint fele a fővárosban realizálódik. $\mathrm{Az}$ ágazat szerepe a fővárosok gazdaságában is folyamatosan nơvekszik, de még messze elmarad a nyugat-európai fövárosok, s különösen a nagyvárosok hierarchiájában magasabb szinten lévő városok gazdaságában betöltött részaránytól (ld. Párizs) (3. táblázat).

\section{TÁBLÁZAT}

A feldolgozóiparban és a fejlett üzleti szolgáltatásokban foglalkoztatottak aránya (\%) (Ratio of Employees in Manufacturing Industry and in Developped Business Services, \%)

\begin{tabular}{lrrrrrrrr}
\hline & \multicolumn{2}{c}{ Budapest } & \multicolumn{2}{c}{ Prága } & \multicolumn{2}{c}{ Varsó } & \multicolumn{2}{c}{ Párizs } \\
\cline { 2 - 9 } & 1995 & 2001 & 1994 & 2001 & 1994 & 2001 & 1994 & 2001 \\
\hline Feldolgozóipar (D) & 18,1 & 14,4 & 14,8 & 10,5 & 25,6 & 14,8 & 8,4 & 6,1 \\
Pénzügyi tevékenység (J) & 3,5 & 3,4 & 3,2 & 4,9 & 6 & 7,8 & 11,1 & 8,9 \\
$\begin{array}{l}\text { Ingatlanügyletek és gazda- } \\
\text { sági szolgáltatások (K) }\end{array}$ & 6,5 & 11,2 & 12,7 & 12,8 & 14,9 & 15 & 18,2 & 22,2 \\
$\begin{array}{l}\text { Fejlett üzleti szolgáltatások } \\
\text { (J és K ágazat) }\end{array}$ & 11 & 14,6 & 15,9 & 17,7 & 20,9 & 22,8 & 29,3 & 31,2 \\
\hline
\end{tabular}

Megjegyzés: Varsó esetében a változó lehatárolás miatt idōben nem összehasonlíthatók az adatok.

Forrás: Bourdeau-Lepage, 2004.

A kelet-közép-európai nagyvárosok gazdasági szerkezete kủlönbözik a nyugateurópai nagyvárosokétól. Az ipar szerepe hagyományosan relatíve jelentősebb, mint a nyugat-európai országokban. Az 1970-80-as évektől az európai nagyvárosokat már a szolgáltatási funkciók dominanciája jellemzi, gazdasági szerkezetủkben az ipar szerepe lecsökkent. Az európai magterület perifériáin található országokban azonban az ipar továbbra is jelentős szerepet kap, elsősorban a külfỏldi beruházásoknak köszönhetően. Ezek döntően a nagyvárosokban, s elsősorban a fővárosokban koncentrálódtak. Spanyolországban a KMT-beruházások 70\%-a Madridban és Barcelonában, Portugáliában pedig 80\%-a Lisszabonban realizálódott. KeletKözép-Európában az 1990-es években, a transznacionális vállalatok beruházásainak köszönhetően az ipari leépülést szintén egy új indusztrializációs fázis kơvette (Enyedi 1998). A gazdasági szerkezet átalakult, új, modern ágazatok jelentek meg.

A kelet-közép-európai országok legfontosabb nagyvárosainak, fövárosainak gazdaságát a magasabb hozzáadott értékủ szolgáltatások mellett az irányító-szervező funkciók erőteljesebb koncentrációja jellemzi. A vállalati székhelyek jelentős hányada összpontosul a fóvárosokban. Csehországban és Lengyelországban a 100 legnagyobb vállalat fele, Magyarországon 45\%-a, Szlovákiában 40\%-a található a legnagyobb városban ${ }^{3}$. A nagyvállalatok nagy számban választják irányító- 
központként a fövárosokat, noha sok esetben a termelés nem itt, hanem az ország más városaiban lévő telephelyen történik. A külföldi vállalkozások esetében a koncentráció foka hasonló. Magyarországon a 100 legnagyobb vállalat közé vidékről csupán négy olyan tudott bekerülni, mely hazai tulajdonban van - miközben Budapesten közel húsz hazai topnagyvállalat is található. Ugyanez jellemzö - még ha nem is ilyen szélsőséges arányban - a többi országban is.

Az elmúlt években számos $\mathrm{K}+\mathrm{F}$-intenzív beruházás jelent meg Magyarországon, csakúgy mint más kelet-közép-európai országban (Uhlír 2004). A transznacionális vállalatok által létesített kutató-fejlesztö helyek jelentős arányban összpontosulnak a fővárosokban. Az itt rendelkezésre álló és koncentrálódó felsỏoktatási bázis folyamatos utánpótlást biztosít azoknak a külföldi vállalkozásoknak, melyek a relatíve kedvező bérköltségủ, de magasan képzett humán erőforrásokat felhasználó vállalati kutatóhelyeket létesítenek Budapesten, Prágában vagy akár Varsóban. Az elmúlt években számos új befektetés célja már a magasabb hozzáadott értékủ $\mathrm{K}+\mathrm{F}$ tevékenység volt, s több száz fős vállalati kutatórészlegek létesültek a kelet-középeurópai nagyvárosokban.

\section{A budapesti metropolisz szerepe a külföldi müködötöke- befektetésekben}

A magyar gazdaság térbeli szerkezete történetileg nagyváros-centrikus (Szirmai 2004). Budapest dominanciája mindig meghatározó volt, de a vidéki „nagyvárosok” szerepe is relatíve jelentős. A transznacionális cégek telephelyválasztási stratégiái még inkább felértékelték a nagyobb városokat és környéküket. A KMT-beruházások vonzásában a centrum-térségek már a rendszerváltás óta kiemelkedtek. A budapesti agglomeráció fejlödése gyorsabb volt, mint az ország màás részeinek növekedése, melyet nagymértékben katalizáltak a KMT-befektetések. Az 1990-es évek közepétöl a budapesti agglomeráción belül megnövekedett a városkörnyék szerepe is: az új beruházások jelentős része az agglomerációs gyürủ városaiban valósult meg. Az észak-dunántúli nagyvárosi, városi térségek (pl. Győrr, Székesfehérvár) kiemelten fejlődtek. Az ország többi nagyvárosa (Pécs, Szeged, Debrecen) kisebb mértékben, de szintén az átlagnál gyorsabban fejlődött. A $K M T$ beruházások új szakaszában a nagyvárosok (Budapest és a régióközpontok) és a már kiépült kapacitások szerepe felértékelődik. $\mathrm{A} \mathrm{K}+\mathrm{F}$, az üzleti szolgáltató központok, a regionális alközpontok számára leginkább a nagyvárosi környezetben kínálkozik megfelelö telephely (Barta-Bernek-Nagy 2003).

A főváros tókevonzó képessége nagyon jelentös, Budapest a legnagyobb gazdasági koncentráció az országban, a legnagyobb fogyasztói, töke-, információs és munkaerőpiaccal rendelkezik. A helyi gazdaság fejlettsége, jelentős gazdasági tradíciói, fejlett infrastruktúrája, képzett munkaerőbázisa, innovációs készsége, a gazdasági szolgáltatások széles és változatos kínálata révên képes kielégíteni a vállalkozások igényeit. Komparatív előnyként jelentkezik a gazdaság agglomerálódása révén számottevöen mérséklödő tranzakciós költségek szintje is. 
A nagyvárosok felértékelödése a külföldi müködőtőke-beruházások telephelyválasztásában. Tér és Társadalom 20. évf. 2006/4. 111-125. p.

Budapesten és agglomerációjában koncentrálodik az országba érkezett töke több mint $64 \%$-a, a főváros részaránya megközelíti az 50\%-ot (4. táblázat). A visegrádi országokba érkezett KMT-befektetések közel egyötödét a budapesti agglomeráció abszorbeálta. Ugyanakkor meg kell említeni, hogy a korábbi dominanciájábol vesztett a magyar föváros, hiszen az 1990-es évek végén a Magyarországra érkezett összes KMT-nek még közel a 70\%-a a Közép-magyarországi régióban koncentrálódott. A budapesti metropolisz tőkevonzó-képessége azonban továbbra is erős, viszont egyre inkább a városhatáron túli területek értékelödnek fel a befektetők szemében. Az agglomerációs gyürü attraktivitása növekszik, s itt jelentős müködőtőke befektetések realizálódnak (Pest megye a Közép-magyarországi régióba érkezó KMT-beruházásokból 1990-es évek közepén 10\%-kal, tíz évvel később 25\%-kal rendelkezett).

\section{TÁBLÁZAT}

A Közép-magyarországi régió részesedése a magyarországi KMT-beruházásokbol (\%)

(Share of Central-Hungary Region in Direct Investments by Foreigners, \%)

\begin{tabular}{lcccccc}
\hline & 1999 & 2000 & 2001 & 2002 & 2003 & 2004 \\
\hline Budapest & 56,3 & 60,1 & 53,9 & 51,9 & 46,8 & 49,3 \\
Pest megye & 6,2 & 8,8 & 11,1 & 11,6 & 15,1 & 15,2 \\
Közép-Magyarország & 62,5 & 68,9 & 65 & 63,5 & 61,9 & 64,5 \\
\hline
\end{tabular}

Forrás: Területi Statisztikai Évkönyv, 1999-2004, KSH, Budapest.

Budapest továbbra is nagy szerepet játszik a KMT-beruházásokban, ugyanakkor a külföldi érdekeltségủ vállalkozások száma, az 1990-es években lezajlott dinamikus növekedéshez képest ma már stagnál. Az újabb tőkebefektetések egyre jelentősebb aránya már nem az új vállalatalapításokhoz kapcsolódik, hanem a már müködö cégek reinvesztícióinak az eredménye. A külföldi beruházók - tőkeemelés és részvényvásárlás révén - egyre inkább kizárólagos tulajdonossá válnak. Ma már a külföldi érdekeltségủ vállalatoknak a $65 \%$. a kizárólag külföldi tulajdonban van, s különösen jellemző ez a közép- és nagyvállalatok esetében. A befektetések húzóereje ma már a reinvesztíció, mely révén a cégek helyi beágyazódása fokozódik.

A külföldi cégek által katalizált fejlödés a fővárosban mára azt eredményezte, hogy a hazai tulajdonban lévö vállalatok is dinamikusabbá váltak. Ma már a fövárosi beruházások kevesebb, mint 30\%-a származik külföldi forrásból, holott az 1990-es években ennek aránya folyamatosan növekedett, s az ezredfordulón közel 45\%-ot tett ki a külföldi cégek részesedése. Tehát a budapesti gazdasági növekedésben egyre markánsabb szerepet játszanak a hazai cégek. Söt, számos cég jelentős tökeexportot bonyolít le. Magyarország a kelet-közép-európai térség vezetö tỏkeexportöre. A külföldi beruházásokban a legfontosabb szerepet a budapesti székhelyú vállalatok játsszák: a külföldi vállalatok felvásárlásában legjelentösebb 12 magyar vállalat közül 8 fővárosi székhelyủ (MOL Rt, OTP Bank Rt, Richter Gedeon Rt, Danubius Rt, Magyar Telekom Rt, Synergon Rt, EGIS Rt, Graphisoft Rt. stb.). 
A magyar tökeexport - a KMT-import elmúlt évekbeli tendenciájával szemben határozottan tovább erősíti Budapest gazdasági pozícióját.

A külföldi beruházások ágazati struktúrája Budapesten eltér az országos trendektől, tercier dominanciájú. A fővárosba érkezett összes KMT-befektetésnek mindössze $40 \%$-a érkezett az iparba, holott az országos átlag $60 \%$ körüli, míg az üzleti szolgáltatások és a kereskedelem a fövárosi külföldi beruházások esetén sokkal jelentősebb szerepet töltenek be, mint vidéken. $\mathrm{Az}$ ipar szerepe ennek ellenére továbbra is nagy jelentőségủ, hiszen az összes beruházásnak mindössze kb. 20\%-a realizálódik a szekunder szektorban. Az ipari beruházásokon belül tehát a külföldi tőke aránya nő, mely lassítja a dezindusztrializációs folyamatokat. Az elmúlt évtizedben a főváros ipara a külföldi töke számára mindig vonzóbb volt, mint a hazai befektetők számára (Barta 2005). Ugyanakkor az évenkénti beruházások összetételét vizsgálva az ezredfordulót követóen új tendenciák körvonalazódtak (5. táblázat), elsősorban a már jelenlévő iparvállalatok invesztícióinak köszönhetỏen. Az elmúlt években a külföldi beruházások tekintetében Budapesten is újra a feldolgozóipar kerïlt az elsö helyre, aránya jelentösen meghaladja az 1990-es évek végi helyzetet. A feldolgozóipar térnyerésével ellenkezö tendenciát mutatott, az 1990-es évek végén még jelentős expanzióval jellemezhetö uizleti szolgáltatások, ill. a távközlés, míg a kereskedelem beruházásai az 1990-es évek végéhez képest megduplázódtak.

\section{TÁBLÁZAT}

Külföldi érdekeltségủ vállalkozások beruházásai Budapesten (\%) (Investments of Companies with Foreign Interest in Budapest \%)

\begin{tabular}{lccccc}
\hline \multicolumn{1}{c}{ Ágazatok } & 1998 & 2000 & 2001 & 2002 & 2003 \\
\hline Feldolgozóipar & 19 & 18 & 27 & 32 & 26 \\
Ũzleti szolgáltatások & 35 & 19 & 17 & 13 & 18 \\
Kereskedelem & 9 & 14 & 15 & 20 & 21 \\
$\begin{array}{l}\text { Szállítás, raktározás, posta, } \\
\text { távközlés }\end{array}$ & 24 & 35 & 26 & 16 & 14 \\
Egyéb & 13 & 14 & 15 & 19 & 21 \\
Összesen & 100 & 100 & 100 & 100 & 100 \\
\hline
\end{tabular}

Forrás: Budapest Statisztikai Évkönyve, 1998, 2003, 2004, KSH, Budapest.

A fövároshoz képest egészen eltérő képet mutat az agglomerációs gyűrủ külföldi beruházási strukturája (6. táblázat). Míg Budapesten a feldolgozóipari beruházások súlya mindössze 20-30\% között marad, a fövárost körülölelő megyében a beruházások fele-kétharmada ezen ágazatban realizálódik. A budapesti agglomerációban a kereskedelem szerepe szintén jelentős, a külföldi beruházások tekintetében a feldolgozóipar után a második legjelentősebb ágazat. Az agglomeráció ipari-kereskedelmi profiljára utal az uzleti szolgáltatások minimális aránya a Pest megyei KMT-beruházásokból. 
A nagyvárosok felértékelődése a külföldi müködőtőke-beruházások telephelyválasztásában. Tér és Társadalom 20. évf. 2006/4. 111-125. p.

TÉT XX. évf. $2006-4$

Gyors ténykép

119

\section{TÁBLÁZAT}

Külföldi érdekeltségü vállalkozások beruházásai Pest megyében(\%)

(Investments of Companies with Foreign Interest in Pest County \%)

\begin{tabular}{lrrrrr}
\hline \multicolumn{1}{c}{ Ágazatok } & \multicolumn{1}{c}{1998} & \multicolumn{1}{c}{2000} & 2001 & 2002 & 2003 \\
\hline Feldolgozóipar & 56 & 43 & 67 & 56 & 56 \\
Üzleti szolgáltatások & 0 & 0 & 3 & 1 & 1 \\
Kereskedelem & 11 & 23 & 9 & 19 & 17 \\
$\begin{array}{l}\text { Szállítás, raktározás, posta, } \\
\text { távközlés }\end{array}$ & 11 & 21 & 9 & 12 & 12 \\
Egyéb & 22 & 13 & 12 & 12 & 14 \\
Összesen & 100 & 100 & 100 & 100 & 100 \\
\hline
\end{tabular}

Forrás: Pest megye Statisztikai Évkönyv, 1998, 2003, 2004, KSH, Budapest.

Az újonnan megjelenő külföldi beruházások a fővárosban továbbra is döntően szolgáltató jellegủek. A Gazdasági és Közlekedési Minisztérium által 2004 és 2006 között bejelentett nagyberuházások között Budapesten kizárólag szolgáltató- és fejlesztôközpontok találhatók (7. táblázat). A 9 bejelentett beruházás több mint 4000 új munkahelyet hoz létre, mindet a tercier szektorban. Az összes hazai nagyberuházásnak ötöde a fővárosban valósul meg, míg az agglomerációs gyürủben egyetlen ilyenre sem akad példa. Azaz újra Budapest válik a nagyberuházások fő célpontjává, $s$ az üzleti szolgáltatások szerepe felértékelődik. Ez még annak a szellemében is igaz, hogy a már itt lévő vállalakozások pótlólagos beruházásai meghaladják az új befektetések arányát.

\section{TÁBLÁZAT}

Külföldi nagyberuházások Budapesten 2004-2006 között (Foreign Capital Constructions in Budapest between 2004-2006)

\begin{tabular}{|c|c|c|c|}
\hline Beruházó & $\begin{array}{c}\text { Erték } \\
(\text { Mrd Ft })\end{array}$ & $\begin{array}{c}\text { Új munkahelyek } \\
\text { száma }(d b)\end{array}$ & Tevékenység \\
\hline EDS* & 11,1 & 1150 & szolgáltató-kðzpont \\
\hline ExxonMobil & 11,2 & 900 & számvitel, IT \\
\hline IBM & 6,4 & 700 & szolgáltatási üzletág bővítése \\
\hline Cisco & 6,5 & 500 & $\begin{array}{c}\text { technológiai támogató } \\
\text { központ }\end{array}$ \\
\hline Morgan Stanley & 6,9 & 450 & pénzügyi szolgáltató központ \\
\hline SAP & 6,5 & 310 & szoftverfejlesztő központ \\
\hline Diageo & 5,3 & 300 & szolgáltató-kózpont \\
\hline Convergys & 3,1 & 300 & szolgáltató-központ \\
\hline Bosch & n.a. & 100 & fejlesztőközpont \\
\hline Összesen* & 56,9 & 4710 & \\
\hline
\end{tabular}

*az EDS beruházásának nem az egésze a fövárosban realizálódik, 4-5 településen szóródik.

Forrás: GKM. 


\section{A húzóágazatok koncentrációja}

A fejlett nagyvárosokban koncentráltan vannak jelen a modem gazdaság húzóágazatai. Hosszú távon a gazdasági dinamika hordozói elsősorban a magas hozzáadott értékkel bíró gazdasági ágazatok. A tudásalapú társadalomban a high-tech és a tudásintenzív tevékenységek szerepe egyre inkább felértékelödik, s a fejlödés húzóerejévé válnak. A high-tech és medium-tech tevékenységek körébe a fejlett gép- és vegyipari tevékenységek tartoznak (Leydesdorff et al. 2006), melyek a hazai GDP közel 10\%-át termelik meg. A tudás-intenzív szektorok közé sorolt szolgáltató tevékenységek állítják elő a hazai GDP több mint egyharmadát. A KMT-befektetések a magasabb technológiai színvonalú, legdinamikusabban fejlödö ágazatokban a legmagasabb szintüek.

\section{TÁBLÁZAT}

A high-tech, medium-tech és tudásintenziv ágazatok területi koncentrációjának mértéke (\%, az ágazat bruttó hozzáadott-értének arányában), 2002

(Rate of Regional Concentration in High-tech, Medium-tech and Knowledge Based Sectors \%, 2002)

\begin{tabular}{|c|c|c|}
\hline ágazatok (TEÁOR kód alapján) & Budapest & $\begin{array}{c}\text { Közép- } \\
\text { Magyarország }\end{array}$ \\
\hline \multicolumn{3}{|l|}{ High-tech ágazatok } \\
\hline $\begin{array}{l}30 \text { - iroda-, számítógépgyártás } \\
32 \text { - híradás-technikai termék, készülék gyártása }\end{array}$ & $\begin{array}{l}10 \\
27\end{array}$ & $\begin{array}{l}14 \\
40\end{array}$ \\
\hline 33 - müszergyártás & 38 & 50 \\
\hline \multicolumn{3}{|c|}{ Medium-tech ágazatok } \\
\hline 24 - vegyi anyag és termék gyártása & 47 & 52 \\
\hline 29 - gép, berendezés gyártása & 18 & 27 \\
\hline 31 - máshova nem sorolt villamos gép gyártása & 27 & 43 \\
\hline 34 - közúti jármü gyártása & 4 & 8 \\
\hline 35 - egyéb jármủ gyártása & 43 & 59 \\
\hline \multicolumn{3}{|l|}{ Tudás-intenzív szektorok } \\
\hline 61 - vízi szállítás & 50 & 55 \\
\hline 62 - légi szállítás & 94 & 98 \\
\hline 64 - posta, távközlés & 57 & 72 \\
\hline 65 - pénzügyi közvetítés & 69 & 72 \\
\hline 66 - biztosítás, nyugdíjalap & 60 & 64 \\
\hline 67 - pénzügyi kiegészítő tevékenység & 42 & 50 \\
\hline 70 - ingatlanügyletek & 40 & 53 \\
\hline 71 - kölcsönzés & 59 & 68 \\
\hline 72 - számítástechnikai tevékenység & 70 & 77 \\
\hline 73 - kutatás, fejlesztés & 70 & 77 \\
\hline 74 - egyéb gazdasági szolgáltatás & 52 & 60 \\
\hline 80 - oktatás & 28 & 37 \\
\hline 85 - egészségügyi, szociális ellátás & 35 & 41 \\
\hline 92 - szórakoztatás, kultúra, sport & 54 & 60 \\
\hline
\end{tabular}

Forrás: Területi Statisztikai Évkönyv, KSH, 2002. 
A nagyvárosok felértékelődése a külföldi müködőtőke-beruházások telephelyválasztásában. Tér és Társadalom 20. évf. 2006/4. 111-125. p.

TÉT XX. évf. 2006 - 4

Gyors ténykép

121

Magyarországon e tevékenységek területi koncentrációja igen nagy. A tudásintenzív szolgáltató tevékenységek kimagasló módon a budapesti metropolisz térségben összpontosulnak, különösen, ami a magas szintü üzleti szolgáltatásokat jelenti. A high-tech és medium-tech feldolgozóipari tevékenységek fővárosi koncentrációja szintén kimagasló. Mindössze a Közép-Dunántúlon koncentrálódó iroda- és számítógépgyártás, valamint a Nyugat-Dunántúlra összpontosuló közúti jármügyártás számít kivételnek (8. táblázat).

\section{Irányitó-döntéshozó központi szerepkör}

A gazdaság irányító, döntéshozó funkciói a nagyvárosokban koncentrálódnak. Budapest vonzza a döntéshozó központokat, a magas szintủ pénzügyi és üzleti szolgáltatásokat stb. Egy kivételével az összes pénzintézet budapesti székhelyú, s az ágazatban megtermelt hozzáadott érték kétharmada a fơvárosból származik, a banki tơkeállomány 95\%-a Budapesten összpontosul. A nagyvállalatok területi elhelyezkedésében is kiemelt szerepe van a fövárosnak.

A Figyelő által készített TOP 200-as listán szereplö cégek területi szerkezete az elmúlt évtizedben jelentős átalakuláson ment keresztuil ${ }^{4}$ (1. ábra, 9. táblázat). Az elmúlt tíz év listáit összevetve az 1990-es évek második felében és az ezredforduló óta eltelt években különböző területi elmozdulások figyelhetők meg.

A listán szereplő vállalatoknak egyre nagyobb hányadát teszik ki a külföldi cégek. Míg az 1990-es évek közepén a 200 cég alig negyede volt külföldi tulajdonban, ma már háromnegyedét irányítják küllföldiek. A 200 legnagyobb vállalat súlya egyre jelentősebb. Az 1990-es évek közepén a kettős könyvelésủ cégek árbevételének egyharmadát adták, 2005-ben pedig a 42\%-át.

A 200 legnagyobb cég területi szerkezetére az 1990-es években nagyon erös budapesti koncentráció volt jellemzö, mely az évtized második felében valamelyest oldódott. Elsősorban Györben, Székesfehérváron és az agglomerációs gyürübe tartozó telepulléseken összpontosultak nagy számban a legnagyobb - néhány kivételtöl eltekintve külföldi - cégek. Az ezredforduló óta eltelt időben a fővárosi agg lomerációs települések súlya számottevỏen emelkedett. Míg az 1990-es évek közepén mindössze négy agglomerációs településen müködött a TOP 200-ba tartozó cég, addig az ezredfordulóra számuk kétszeresére, 2004-re pedig háromszorosára nőtt: ma már 12 agglomerációs telepưlésen van legalább egy, de Budaörsön 12 topcégnek is a székhelye. A budapesti metropolisz súlya az ezredforduló óta összességében növekszik. A TOP 200-ból egyre több vállalat székhelye koncentrálódik a fővárosi agglomerációban, s az összárbevétel kétharmada is itt összpontosul. 


\section{1. ÁBRA}

A TOP200 vállalat székhely szerinti elhelyezkedése az árbevétel alapján 1994-ben, 2000-ben és 2004-ben (az összárbevétel százalékában)

(Principal Office Location of TOP 200 Companies According to their Incomein 1994, 2000 and 2004)
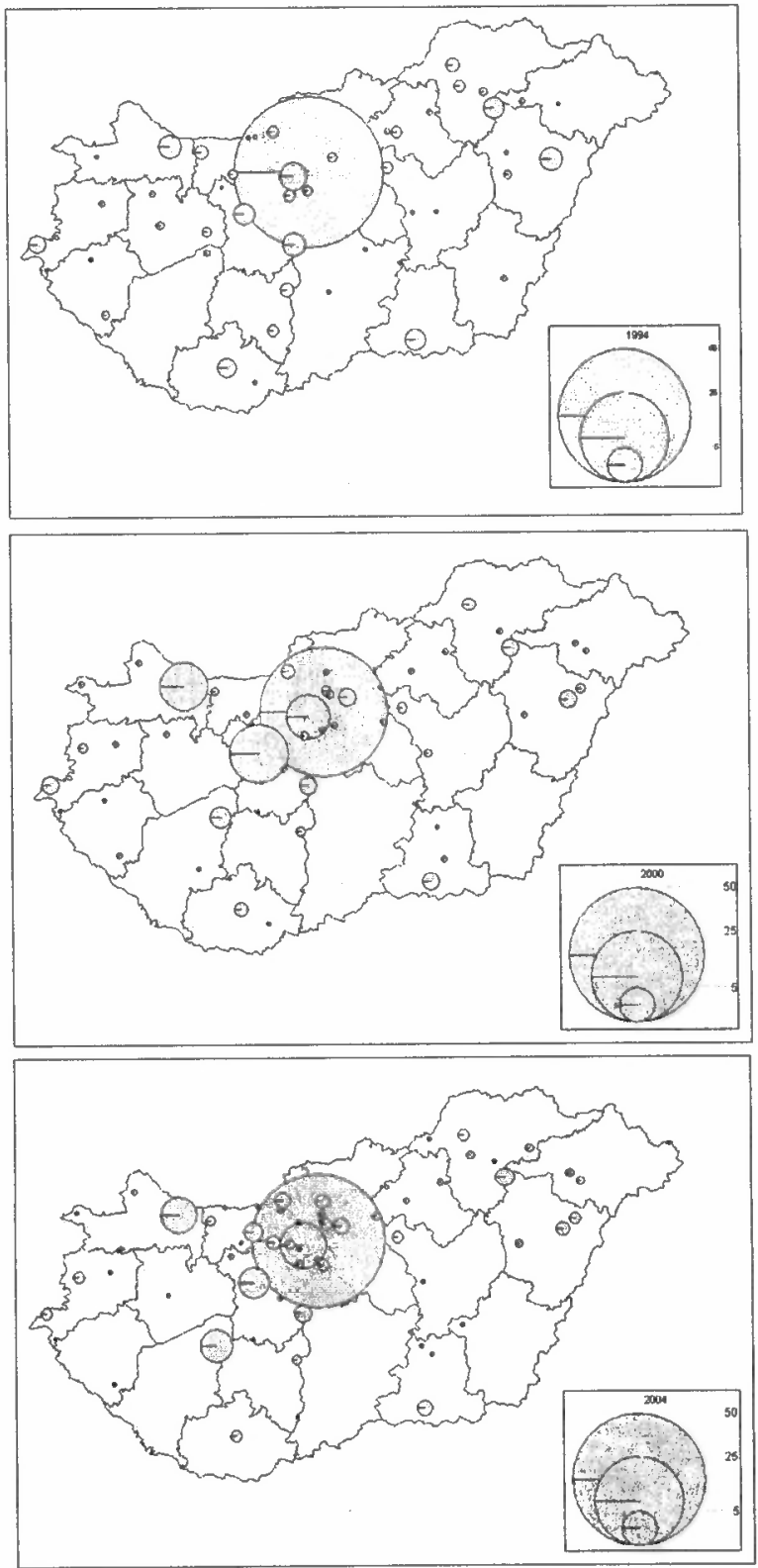

Forrás: Figyelö TOP 200, 1994, 2000, 2004. 
A nagyvárosok felértékelődése a külföldi müködőtőke-beruházások telephelyválasztásában. Tér és Társadalom 20. évf. 2006/4. 111-125. p.

TÉT XX. évf. 2006 - 4

Gyors ténykép 123

\section{TÁBLÁZAT}

A TOP200 vállalat budapesti koncentrációjának változása (Change of Budapest'Concentration of TOP 200 Companies)

\begin{tabular}{lcccccc}
\hline & \multicolumn{2}{c}{1994} & \multicolumn{2}{c}{2000} & \multicolumn{2}{c}{2004} \\
\cline { 2 - 7 } & $\begin{array}{c}\text { cégek } \\
\text { száma } \\
(\%)\end{array}$ & $\begin{array}{c}\text { árbevé- } \\
\text { tel }(\%)\end{array}$ & $\begin{array}{c}\text { cégek } \\
\text { száma } \\
(\%)\end{array}$ & $\begin{array}{c}\text { árbevé- } \\
\text { tel }(\%)\end{array}$ & $\begin{array}{c}\text { cégek } \\
\text { száma } \\
(\%)\end{array}$ & $\begin{array}{c}\text { árbevé- } \\
\text { tel }(\%)\end{array}$ \\
\hline $\begin{array}{l}\text { Budapest } \\
\text { Agglomerációs } \\
\text { gyürú }\end{array}$ & 53 & 64 & 53 & 48 & 51 & 52 \\
\hline
\end{tabular}

Forrás: Figyelö Top200, 1994, 2000, 2004.

\section{$K+F$ központi szerepkör}

A KMT-befektetések nagyvárosi térségekbe történő koncentrálódásának vizsgálatakor külön említést kell tenni a kutatás-fejlesztési tevékenység növekvő szerepéröl. A kihelyezett $\mathrm{K}+\mathrm{F}$ tevékenység számottevő hatással van a helyi gazdaságra. A $\mathrm{K}+\mathrm{F}$ jelentős szerepet játszik a gazdasági fejlődésben, hozzájárul a gazdasági modernizációhoz és dinamizáló hatása van a térség gazdaságára. Segíti a külföldi töke beágyazódását, a KMT befektetések esetében növekszik a hozzáadott érték, $\mathrm{s}$ a hazai $\mathrm{K}+\mathrm{F}$ tevékenységet is közelíti a nemzetközi színvonalhoz.

A külföldi töke megjelenésekor még kivételnek számított, hogy a kulföldi beruházó jelentős $\mathrm{K}+\mathrm{F}$ tevékenységet folytatott a fogadó országban. Ennek motivációi között általában a magas szintü helyi kutatói potenciál (Ericsson, Nokia), ill. a korábban elért komoly eredmények lehetnek mérvadóak (GE Tungsram, GE Medicor, Chinoin, Siemens). Az 1990-es évek második felétől kezdődően azonban egyre több multinacionális cég telepített $\mathrm{K}+\mathrm{F}$ tevékenységet is más országokba. Így például a GE, az IBM, a Cisco, a SAP, a Siemens, a Knorr-Bremse stb. létesített és bővített kutatólaboratóriumot, fejlesztőközpontot Magyarországon, elsősorban a budapesti agglomerációban. Ez az uzleti szféra növekvő $\mathrm{K}+\mathrm{F}$ aktivitását, illetve Magyarország, Budapest minöségi felértékelödését mutatja. A - zömében multinacionális - vállalati kutatóhelyeken dolgozó szakemberek száma 1996 óta kétszeresére nött, $\mathrm{s}$ megközelíti a kilencezer főt. A vállalati kutatók számát tekintve Budapest dominanciája megkérdőjelezhetetlen $(61 \%)$. A budapesti vállalkozások $\mathrm{K}+\mathrm{F}$ létszáma kb. 5000 föt tesz ki, mely jellemzően néhány nagyvállalatra koncentrálódik, elsösorban a gyógyszeriparban, az infokommunikációs szektorban és a gépiparban. Egyes cégek több száz fős kutatóintézetet hoztak létre a fövárosban (GE, Richter, Siemens, Nokia, Ericsson, EGIS, IBM, Chinoin, T-Systems stb.), Vidéken kevés a vállalati kutatóhely, $\mathrm{s}$ csak kevés olyan multinacionális cég van, mely számottevö $\mathrm{K}+\mathrm{F}$ tevékenységét telepített vidéki telephelyre (pl. Audi - Györ, Bosch Miskolc stb.). 


\section{Összefoglalás}

A nagyvárosi térségek a globális gazdaságban kulcsszerepet töltenek be, a modernizáció és megújulás legfontosabb helyei. A globális gazdaság föszereplői, a transznacionális vállalatok a nagyvárosi környezetben koncentrálódnak. A posztindusztriális nagyvárosok gazdaságában meghatározó szerepet kapnak a fejlett uizleti szolgáltatások s az információs gazdaság. Ugyanakkor a high-tech ágazatok is e térségekben összpontosulnak.

A kelet-közép-európai térségben a nagyvárosok, s elsősorban a fővárosok szerepe szintén felértékelődött: a politikai és igazgatási irányító funkciók koncentrációja mellett a gazdaságirányítás is itt összpontosul. A transznacionális vállalatok is a fóvárosokat preferálják. Magyarországon a Budapesti agglomerációban koncentrálódik a KMT- befektetések közel kétharmada. A tudásintenzív, magasabb hozzáadott értéket lehetôvé tevő befektetések körében Budapestnek alig van alternatívája az országban - a vállalati $\mathrm{K}+\mathrm{F}$ helyek, a regionális szolgáltató-központok többsége a fóvárosban jön létre.

Mivel az újabb tőkebefektetések egyre jelentősebb aránya már nem az új vállalatalapitásokhoz kapcsolódik, hanem a már müködö cégek reinvesztícióinak az eredménye, igy a budapesti metropolisz tovább szilárdítja, ill. erósíti pozícióit. A külföldi vállalatok tevékenységének lassú tercierizálódása ugyancsak a nagyvárosi központok, elsősorban Budapest jelentőségét erỏsíti. Az új nagyberuházások döntő része a szolgáltató ágazatban realizálódik, míg az ipari beruházások előszeretettel választják a nagyváros környékét. Az ezredforduló után azonban a feldolgozóipari beruházások súlya újra nőtt a KMT-beruházásokon belül, kisebb mértékben a fövárosban, dinamikusan az agglomerációs gyürüben. A szolgáltatásokban, a high-tech és tudásintenzív ágazatokban a növekedés zöme a fövárosban összpontosult. A főváros felértékelödését jelzi a $\mathrm{K}+\mathrm{F}$ beruházások terén kiharcolt pozíciója is. A külföldi nagyvállalatok egyre nagyobb száma koncentrálódik a fóvárosi agglomerációban. Budapest irányító funkciója tovább növekszik, a külföldi befektetéseket tekintve a fővárosi metropolisz súlya szilárd, sőt a magasabb hozzáadott-értékü beruházások növekvő expanziója révén erösödö.

\section{Jegyzetek}

${ }^{1}$ Európai szinten a legalább félmilliós városokat tekintik nagyvárosnak, a kelet-közép-európai szakirodalomban megjelenő osztályozásokban már a 100-500 ezer fős városok is nagyvárosoknak számítanak (Keresztély-Jeney 2003).

${ }^{2}$ A rendelkezésre álló statisztikákban, néhány esetben a terulleti lehatárolás köre különbơzö, így összehasonlításuk nehézségekbe ütközik. Csehországban a föváros, Szlovákiában a kissé kibővített fơvárosi agglomeráció (Pozsonyi régió), Magyarországon, s még inkább Lengyelországban a jelentős vidéki területeket (Közép-Magyarország, ill. Mazowiecki-Varsói régió) is magába foglaló fövárosi régiók képezik a vizsgálat tárgyát, mivel csak ezeken a területi szinteken állnak rendelkezésre elérhetö adatok.

${ }^{3}$ Magyarországon a Figyeló top 200-as, Lengyelországban a Rczecpospolita top 500-as, Szlovákiában az E-trend top 100-as, Csehországban pedig a www.czechtop 100.cz top 100-as listájának 2005-ös adatait vizsgáltuk. 
${ }^{4}$ A Figyelő TOP 200-as kiadványában nem minden cég engedélyezi adatainak közzétételét. Az 1994-es toplistán 30 cég sora maradt üresen, 2000-ben már csak 13 cég nem tette nyilvánossá adatait. 2004-ben 200 cég szerepelt a listán, ekkor már nem jelezték kưlòn az adatot nem szolgáltató cégek helyét. Ugyanakkor egyre kevesebb cég tiltja meg adatainak közlését, ill. zárkózik el a felméréstöl. A legnagyobb cégek közőtt ilyen, pl. a Nokia.

\section{Irodalom}

Barta Gy.-Bernek Á.--Nagy G. (2003) A külföldi müködőtőke-befektetések jelenlegi tendenciái és teruleti elmozdulásának esélyei Magyarországon. - Tér és Társadalom. 3-4. 173-190. o.

Barta Gy. (2005) Nemzetközi funkciók. Munkamegosztás a hét nagyváros között Magyarországon. Falu-Város-Régió. 3-4. 35-42, o.

Bourdeau-Lepage, L. (2004) Metropolization in Central and Eastern Europe: Unequal Chances. - GaWC Research Bulletin 141. 24. o.

Castells, M. (1996) The Rise of the Network Society. Blackwell, Oxford.

Cséfalvay Z. (1999) Helyünk a nap alatt. Magyarország és Budapest a globalizáció korában. Kairosz Kiadó, Budapest.

Enyedi Gy. (1997) A sikeres város. - Tér és Társadalom. 4. 1-7. o.

Enyedi Gy. (2001) A nagyvárosi régiók és a globális gazdaság. - Comitatus. 7-8. 7-19. o.

Enyedi, Gy. (szerk.) (1998) Social Change and Urban Restructuring in Central Europe. Akadémiai Kiadó, Budapest.

Erdősi F. (2003) Globalizáció és a világvárosok által uralt tér I-II. - Tér és Társadalom. 3., 4. 1-28. o., 1-16. o.

Friedmann, J. (1995) The World City Hypothetis. - Knox, P.-Taylor, P. (eds.) World Cities in a WorldSystem. Cambridge University Press. 317-331. o.

Hall, P. (1966) The World Cities. Weidenfeld and Nicholson Publishers, London.

Keresztély K.-Jeney L. (2003) Az Európai városhierarchia és városverseny jellemzői. Kézirat. MTA RKK. 93. 0. Krätke, S. (2006) The Metropolization of the European Urban and Regional System. - GaWC Research
Bulletin. 193 o.

Krugman, P. (2000) A földrajz szerepe a fejlődésben. - Tér és Társadalom. 4. 1-2l. o.

Lengyel I.-Rechnitzer J. (2000) A városok versenyképességéröl. - Horváth Gy.-Rechnitzer J. (szerk.) Magyarország területi szerkezete és folyamatai az ezredfordulón. MTA RKK, Pécs. 130-153. o.

Leydesdorff, L.-Dolfsma, W.-Van der Panne, G. (2006) Measuring the knowledge-base of an economy in terms of triple helix relations among "technology, organization, and territory". - Research Policy. 35. 181-199. o.

Lichtenberger, E. (1994) Das metropolitane Zeitalter in Europa in West und Ost. Mitteilungen der Österreichischen Geographischen Gesellschaft. 136. 7-36. o.

Nagy G. (2006) Várostérségek és gazdasági versenyképesség. - Csapó T.-Kocsis Zs. (szerk.) Agglomerációk és szuburbanizálódás Magyarországon. Berzsenyi Dániel Föiskola Társadalomföldrajzi Tanszék. 215-226. o.

Raffay, Z. (2005) The Role of Business Services in the Development of Peripherial Regions. - Barta, Gy.G. Fekete, E.-Szörényiné Kukorelli, I-Timár, J. (szerk.) Hungarian Spaces and Places: Patterns of Transition. Centre for Regional Studies, Pécs. 182-196. o.

Sassen, S. (1991) The Global City: New-York, London, Tokyo. Princeton University Press, Princeton.

Sassen, S. (2000) New frontiers facing urban sociology at the Millennium. - The British Journal of Sociology. 1. 143-161.0.

Sykora, L. (1996) Metropolises in Transition, Metropolises in Competition: Globalization of Central European Cities and their Integration into European Urban Network. - European Conference Proceedings, Urban Utopias: New Tools for the Renaissance of the City in Europe. CD-ROM, TVVF.
Berlin.

Szirmai V. (2004) Globalizáció és a nagyvárosi tér társadalmi szerkezete. - Szociológiai Szemle 4. 3-24. o.

Uhlír, D. (2004) Regional versus national development: What sort of policy for the new czech regions? Drbohlav; D.-Kalvoda, J.-Vozenilek, V. (eds.) Czech geography at the Dawn of the Millenium. Palacky University in Olomouc, Olomouc. 269-277. o. 